\title{
EFA of Pedagogic Competence Instrument to Measure Teacher Performance
}

\author{
Eko Wahyunanto Prihono ${ }^{1,2^{*}}$, Fitria Lapele ${ }^{2}$, Siti Jumaeda ${ }^{2}$, Sukadari Sukadari ${ }^{3}$, \\ Siti Nurjanah ${ }^{2}$ \\ ${ }^{1}$ Post Graduate Program of Universitas Negeri Yogyakarta, Indonesia \\ ${ }^{2}$ Faculty of Education and Teacher Training, Institut Agama Islam Negeri Ambon, Indonesia \\ ${ }^{3}$ Post Graduate Program of Universitas PGRI Yogyakarta, Indonesia \\ "Corresponding author.Email: ekowahyu.2021@student.uny.ac.id, ekowahyunantoprihono@gmail.com
}

\begin{abstract}
The purpose of this research was to determine the feasibility of the instrument in terms of construct validity test of exploratory factor analysis (EFA) on pedagogic competence instrument to measure the teachers' per-formance. The focus was on describing the decisions made in EFA. The method used in this research was the instrument development with a response approach. The results showed that the instrument has been de-clared feasible in terms of: 1) the index of the distance comparison between the correlation coefficient and the partial correlation coefficient is fulfilled, it was proven that the KMO value was $>0.5 ; 2$ ) the factors that can be arranged in this variable were twelve factors with four was being the most dominant factors.
\end{abstract}

Keywords: exploratory factor analysis (EFA), measurement, pedagogic competence instrument, teacher performance.

\section{INTRODUCTION}

Teachers are professional educators with the main task of educating, teaching, guiding, directing, training, assessing, and evaluating students at the level of preschool, formal, basic, and secondary education. In carrying out their duties, they apply expertise and skills as the evidence of their performance. The performance is a work performance, work implementation, work achievement, and work result or performance [1], [2]. Teachers performance can be measured based on the specification or competency criteria that must be possessed by every single teacher [3].

The dimensions of teachers performance are categorized in several ways, including population morality, showing identity and support in the organization, having work dedication, assistance and cooperation which refers to teachers behaviour such as helping colleagues, having good relationship with students' parents, teaching effectively, interacting with students inside or outside the classroom [4], [5].
Teachers performance is the embodiment of competence possessed by the teacher. It can be interpreted that the teachers will not be able to perform according to their expertise if they do not have the relevant competence. The competence comes from within and is an extension of one's personality. Thus, it has high self-ability. Teachers are always required to improve these competencies because teachers are the main role model for students. The principle of competence in a teacher is being able to appreciate the expertise of the subject being educated as the most important indicator. [6], [7].

One of the competencies that teachers must take is pedagogic competence. It is displayed by the teachers as their performance when carrying out the duties in designing, preparing, implementing, and assessing learning processes and outcomes. Several aspects contained in the pedagogic competence are elements used to assess teachers performance [8]-[10]. Therefore, it is necessary to classify teachers performance in terms of pedagogical competence to determine the dimensions based on the loading factor of items using Exploratory 
Factor Analysis (EFA). The purpose of EFA is to find the latent structure of the observed variable by revealing the common factors and hidden dimensions that can affect the measured variable [11]. In addition, the dimensions and indicators of this concept need to be tested again for their suitability in the context of teachers performance [12].

EFA is a way to detect and assess latent sources of variation in a measurement. It is exploring empirical data to find and detect characteristics and relationships between variables without specifying a model on the data. An exploratory approach is used to see how many factors are needed to explain the relationship between a set of indicators by observing the magnitude of the loading factor.

The results of the study need to be proven empirically, especially in answering questions related to pedagogic competence. Thus, further research is needed to test the validity of the pedagogical competence construct empirically. An important benefit of the test is to prove whether pedagogic competence is a unique construct and has not been accommodated in existing concepts of teacher performance. This research was done to test the hypotheses regarding the existence of constructs in the variables of pedagogic competence as independent constructs. The studies conducted through construct validity tests are needed to confirm whether the construct of pedagogic competence is an independent construct or vice versa.

\section{RESEARCH MATERIAL}

\subsection{Pedagogic Competence}

The pedagogic competence in general terminology is associated with the study of the problem of guiding students towards certain learning goals [13], [14]. The pedagogic competence is substantively related to the ability to understand students, design and implement learning, evaluate learning outcomes, and develop students to actualize their various potentials [15], [16].

Several previous researches explained that the abilities teachers must have regarding observed aspects include 1) mastery of student characteristics from physical, moral, social, cultural, emotional, and intellectual aspects, 2) mastery of learning theory and educational learning principles, 3) developing curricula related to effective development fields, 4) organizing educational development activities, 5) using information and communication technology to organize educational development activities, 6) facilitating potential development students to actualize their various potentials, 7) communicating effectively, empathize, and politely with students, 8) evaluating the learning process, and utilizing the results of the assessment and evaluation for the benefit of learning [17].
In the aspect of pedagogic competence, the teachers should understand the characteristics of elementary school students related to the physical, intellectual, socio-emotional, moral, spiritual, and socio-cultural background aspects. In addition, the teachers are also expected to be able to identify the students' early abilities and potential. Futhermore, the teachers must be able to identify students learning difficulties [18], [19].

\subsection{Exportation Factor Analysis}

\subsubsection{Variable Selection}

The selection of variables is done by looking at the strong correlation between items and will be included in the factor analysis. Otherwise, items with weak correlation will be excluded from factor analysis [20], [21]. The focus in this analysis is the measure of correlation between items that are based on the early teachers performance indicators. This is done to identify relationships within the set of items. One way to determine the correlation between items can use the Measure of Sampling Adequacy (MSA) and the KaiserMeyer-Olkin (KMO) measure of sampling adequacy and Bartlett test of sphericity are used for this purpose [22]. The MSA value can be seen from the acquisition of anti-image correlation. If there is an initial item that has an MSA value $<0.5$, then the item is removed from the analysis process [23]. After obtaining the items that match the indicators (MSA > 0.5), the next step is to test the adequacy of the sample by seeing at the KMO measure of sampling adequacy index. The accepted KMO value is between 0.5 and 1 .

\subsubsection{Factor Formation}

\subsubsection{Principal Component Model}

One approach to factor analysis can be done through EFA with the principal component analysis method. It aims to determine the underlying structure of the early items in the analysis and to simplify the structure of the initial set of items through data reduction [11].

\subsubsection{Factor Determination Criteria}

The approach used to determine the number of factors obtained in this research is seen from three criterias: eigen value, percentage variance, and scree plot. The eigen value indicate the amount of variation associated with a factor. Factors that have an eigen value of 1 will be maintained and factors that have an eigen value of $<1$ will not be included in [24], [25]. The number of factors taken is determined based on the cumulative number of variations that have been achieved. If the cumulative value of the percentage of variance is sufficient (more than half of the entire 
variance of the initial variable), then factor extraction can be stopped.

The scree plot is a graph that shows the relationship between factors and their eigen value. Determination of these criteria is done by plotting the eigen value against the number of factors to be extracted. The eigen value are plotted in the vertical direction, while the number of factors $(\mathrm{m})$ is plotted in the horizontal direction. The number of factors in this criterion is determined based on the slope of the eigen value plot. When the scree starts to level off and the eigen value is more than one and less than one, this is where the factor number extraction stops. The point indicates the number of factors that can be extracted.

\subsubsection{Factor Rotation}

The rotation process is done to obtain simplicity of the factors and increase their interpretation ability. The rotation method in factor analysis that continues to be developed by many researchers is the orthogonal rotation method and the oblique rotation method. Orthogonal rotation is a rotation that is done by keeping the axes perpendicular to each other. By doing this rotation, each factor is independent of other factors because its axes are perpendicular to each other. Orthogonal rotation is used when the analysis aims to reduce the number of variables without considering how significant the extracted factors are. The oblique rotation does not maintain the perpendicular axis anymore. With this rotation, the correlation between factors is still taken into account because the axes of the factors are not perpendicular to each other. Oblique rotation is used to obtain a theoretically significant number of factors.

In this research, the orthogonal rotation method was used through the varimax measurement results. Varimax analysis focuses on simplifying factor matrix columns. Maximum simplification occurs when there are only 0 and 1 values in a column. In this method there is a tendency to produce several high loading factor values (close to -1 or +1 ) and several loading factor values close to 0 in each matrix column [24], [26]. The logic of interpretation will be easier when the correlation between factors and variables is +1 or -1 because this indicates a perfect association that is positive or negative. A value of 0 indicates a very poor association. The varimax technique tries to produce a large factor loading value or other factors as small as possible. The resulting structure is much simpler when compared to the quartimax method. In addition, this varimax method can distinguish factors more clearly.

\subsubsection{Factor Naming}

The naming of factors is done by looking at the things that underlie and adequately represent the properties of the initial items collected in one factor. Steps that can be taken are to apply generalizations to the initial items. This can be seen from the loading factor value obtained by each item by comparing the loading factor value of the variables in the formed factor. Determination of the significance of loading factor is carried out using a significance level $(\alpha)$ of 0.05 [24]. Rules are set to identify significant loading factor based on the sample size [11]. An item is said to have a significant factor loading if it has a value above 0.3 [22]. Thus, to make visualization easier, the loading factor values displayed are only those with values above 0.3 .

\section{RESEARCH METHOD}

This research used the method of developing teachers performance instruments in terms of pedagogic competence. The purpose of this research was to determine the feasibility of the instrument in terms of construct validity test of pedagogic competence to measure teachers performance. The researchers try to explore how many factors are formed from the construct of teachers performance in terms of pedagogic competence by using Exploratory Factor Analysis (EFA). EFA is a multivariate statistical technique used to extract indicators of teachers performance. Each indicator is ranked based on the highest percentage of the calculated variation. The factor extraction method used is orthogonal with varimax factor rotation. The extraction method was chosen because it can provide significant test results to determine the number of factors on the measured variables. Varimax factor rotation was chosen because this rotation method makes the factors independent of each other [27].

The indicators and dimensions for teachers performance refer to items that are arranged based on the pedagogic competencies that teachers must possess. The number of initial indicators obtained by the researcher was 10 indicators, but in this paper, the focus on the first four indicators that describe teachers performance variables. Furthermore, the test items are arranged based on the nineteen sub-indicators in it. The nineteen sub-indicators contain 35 test items. Sampling used in this research is cluster random sampling technique. This technique is carried out through grouping elementary schools in each sub-district in Bantul Regency. The subjects of this study amounted to 144 respondents, with the following criteria: 1) elementary school laboratory teachers at PGRI Yogyakarta University; 2) teach in elementary schools in high grade IV or V or VI; and 3) willing to participate in the research. The data collection technique in this study used a multiple-choice objective test instrument with a polytomus scale, that is, each test answer option has a different score. 


\section{RESULT \& DISCUSSION}

\subsection{Result}

\subsubsection{Variable Selection}

The researchers used Measure of Sampling Adequacy (MSA) to determine the correlation between items. The MSA value can be seen from the acquisition of anti-image correlation. There are initial items that have an MSA value < 0.5, items A.2.2.1 and A.4.6.1 so that these items are excluded from the analysis process. After obtaining the items that match the indicators (MSA > 0.5), the next step is to test the adequacy of the sample. The sample adequacy test is seen from the size of the KMO measure of sampling adequacy index. The range between the correlation coefficient and the partial correlation coefficient in terms of the KMO measure of sampling adequacy shows in the good category with the resulting value of $0.743(>0.5)$. It shows that the adequacy of the sample in this study is considered sufficient. In addition, the adequacy of the sample is strengthened by a Chi-Square value of 1212,314 with a degree of freedom (df) of 528 and a p value (Sig.) of 0.000 (<0.01). This shows that the Bartlett Test of Spericity meets the requirements of the next test because the significance is below $0.01(1 \%)$ and indicates that the sample size of 144 respondents used in this factor analysis is sufficient [24].

\subsubsection{Factor Formation}

After the items that describe the variables are determined and selected and the correlation calculations have met the requirements for analysis, the next step is to form factors to find the structure that underlies the relationship between these initial items. One approach to factor analysis can be done through exploratory factor analysis with the principal component analysis method. The approach used to determine the number of factors formed can be seen from: 1) eigenvalues, 2) percentage variance and 3) scree plot. A total of twelve factors have eigenvalues 1 , thus, the twelve factors are maintained. The factor extraction was carried out on 33 items. There are twelve factors with a cumulative variance value of $65.740 \%$. This value is quite good because the total variance that can be explained is more than $50 \%$. However, of the twelve factors formed, there are four factors that are the most dominant in measuring teacher performance in terms of pedagogic competence. Next, the researchers simplify the acquisition of factors. This can be seen through the value of the loading factor resulting from the rotation process using the orthogonal rotation method through the varimax measurement results. An item is said to have a significant loading factor if it has a value > 0.3 [22]. Thus, to make visualization easier, only the loading factor values displayed are $>0.3$. From these results, it can be seen that each of these test items has a tendency to cluster in twelve factors with 3 factors being the most dominant. Although there are items that have a significant loading factor on more than one factor. However, these items are not evaluated at this stage because the EFA is used to identify the number of factors that make up the academic resilience scale.

\subsubsection{Naming Factors}

The naming of factors in this research is seen from the loading factor value obtained by each item by comparing the loading factor value of the variables in the formed factors. The naming of the factors is given based on the grouping of indicators indicated by the factor load of each indicator.

\subsection{Discussion}

Teachers are role models for students both at school and outside school. It is appropriate if the teachers must have broad knowledge, mature personality, good social attitude, and professionalism in work. The teachers' ability to apply these skills and abilities is evidence of his performance. Teacher performance is an embodiment of the competencies possessed by teachers [28]. The best competencies can be described with a fairly complex combination including: knowledge, skills, understanding, values, affective attitudes that are manifested by actions in certain circumstances[29].

One of the competencies that teachers must have is pedagogic competence. It is necessary to classify the teacher's performance in terms of pedagogic competence to determine the dimensions based on the factor load of the items. It is done to find the latent structure of the observed variables by revealing the same factors and hidden dimensions that can affect the teacher's performance variable. In addition, the dimensions and indicators of this concept need to be tested again for their suitability in the context of teacher performance.

An exploratory approach is used to see how many factors are needed to explain the relationship. Before conducting an exploratory factor analysis, it is necessary to determine the variables and formulate the indicators contained in the components of teacher performance [23]. Furthermore, it is necessary to conduct a feasibility test of the instrument to see the suitability of the indicators with the teacher's performance test items. This is done to select items that match the indicators that describe the teacher's performance variables. If there are items that are not relevant to the indicator, then the item will be revised or replaced.

Based on the Measure of Sampling Adequacy (MSA) there are two items that have a low correlation between items, namely A.2.2.1 and A.4.6.1 items. After 
further investigation, it was found that the correlation between the two items was only 0.398 and $0.479(<0.5)$ [22]. The item A.2.2.1 describes the application of various learning approaches and item A.4.6.1 describes how to make transactional decisions in five subjects at the elementary school level. Overall, of the 35 items tested, 33 items are eligible to be used to measure teacher performance in terms of pedagogic competence.

These indicators and dimensions for teacher performance refer to items that are arranged based on the pedagogic competencies that teachers must possess. The number of initial indicators obtained by the researcher was 10 indicators, but in this paper focus on the first 4 indicators that describe teacher performance variables. Furthermore, the test items are arranged based on the 19 sub-indicators in it. The nineteen subindicators contain 35 test items. Furthermore, the researchers conducted the formation of factors referring to the structure that underlies the relationship between items through exploratory factor analysis with the principal component analysis method.

The results of the analysis in terms of eigenvalues, percentage of variance and scree plots showed that as many as twelve factors had an eigenvalue of 1 so that the twelve factors were maintained [24], [30]. The twelve factors formed include: understanding students, developing curriculum, applying learning approaches, understanding educational foundations, identifying learning difficulties, developing lesson plans, using learning media, determining student learning experiences, identifying student potential, understanding student characteristics, implementing learning in a holistic manner, comprehensive, learning design principles.

Based on the grouping and naming of the twelve factors, it confirms that there are important aspects in the pedagogic competence of elementary school class teachers that are integrated in teacher performance, where teachers must have the ability to understand student characteristics and master the field of study, both in terms of science and education [30] In addition, pedagogic competencies that show teacher performance can be viewed from the mastery of learning theory and educational learning principles.

\section{CONCLUSION}

The testing of Exploratory Factor Analysis in this study find the latent structure of the items in the teacher's performance construct. Extraction and rotation of these items can reveal common factors and hidden dimensions in the construct of teacher performance in terms of pedagogic competence. Thus, this construct can be a teacher performance variable containing at least twelve factors. The test of Exploratory of Factor Analysis conducted in this study showed that all 33 test items were eligible to be used as indicators because they had a good anti-image correlation coefficient. From the extraction and rotation of factors, 12 dimensions/factors were produced with a cumulative variance value of $65.740 \%$, this value is quite good because the total variance that can be explained is more than $50 \%$.

The resulting of twelve factors can be used as dimensions of teacher performance variables in terms of pedagogic competence. The dimensions of the teacher performance variable in terms of the pedagogic competencies offered in this study, including: 1) understanding students, 2) developing curriculum, 3) applying a learning approach, 4) understanding educational foundations, 5) identifying learning difficulties, 6) developing learning plans, 7) using learning media, 8) determining student learning experiences, 9) identifying student potential, 10) understanding student characteristics, 11) implementing comprehensive learning, and 12) learning design principles.

\section{AUTHORS' CONTRIBUTIONS}

Eko Wahyunanto Prihono: conceptualization, methodology, data validation, formal analysis, author of the original draft, \& editing. Fitria Lapele: translater \& editing. Siti Jumaeda: review. Sukadari Sukadari: data provider \& review. Siti Nurjanah: data provider \& editing.

\section{ACKNOWLEDGMENTS}

The researchers would like to thank the: 1) PGRI Yogyakarta University for providing facilities, moral support and permission to researchers to collect data. 2) All parties who have provided valuable information needed in this research.

\section{REFERENCES}

[1] J. P. Papay, E. S. Taylor, J. H. Tyler, and M. E. Laski, "Learning job skills from colleagues at work: Evidence from a field experiment using teacher performance data," Am. Econ. J. Econ. Policy, vol. 12, no. 1, pp. 359-388, 2020.

[2] A. Sudirman, D. Lie, S. Sherly, and E. Dharma, "The Impact of Work Discipline and Work Ethic on the Teacher Performance of Sultan Agung Pematangsiantar Private Middle School Teachers TA 2018/2019,” Int. J. Bus. Stud., vol 3, no. 3, pp. 125-135, 2019.

[3] T. H. Retnowati, D. Mardapi, B. Kartowagiran, and S. Suranto, "Model evaluasi kinerja dosen: pengembangan instrumen untuk mengevaluasi kinerja dosen," J. Penelit. dan Eval. Pendidik. vol. 21, no. 2, pp. 206-214, 2017.

[4] M. Arman, B. T. Syamsul, and M. Darman, "The effect of school supervisors competence 
and school principals competence on work motivation and performance of Junior High School teachers in Maros Regency, Indonesia," Int. J. Environ. Sci. Educ., vol. 11, no. 15, pp. 7309-7317, 2016.

[5] H. Jamin, "Upaya Meningkatkan Kompetensi Profesional Guru," At-Ta'dib J. Ilm. Prodi Pendidik. Agama Islam, pp. 19-36, 2018.

[6] U. Rusilowati and W. Wahyudi, "The Significance of Educator Certification in Developing Pedagogy, Personality, Social and Professional Competencies," in 2nd Social and Humaniora Research Symposium (SoRes 2019), 2020, pp. 446-451.

[7] E. W. Prihono and S. Supahar, "The Measurement of Professional Competency to School Teacher's Achievement at PGRI University Yogyakarta Laboratory," Refleks. Edukatika J. Ilm. Kependidikan, vol. 8, no. 2, 2018.

[8] B. Kartowagiran, "Revitalisasi Sertifikasi Guru Untuk Mewujudkan Tenaga Kependidikan Profesional." 2016.

[9] S. Syahrial et al., "The Impact of Etnocontructivism in Social Affairs on Pedagogic Competencies.," Int. J. Eval. Res. Educ., vol. 8, no. 3, pp. 409-416, 2019.

[10] K. Khofiatun and M. Ramli, "Peran Kompetensi Pedagogik Guru Dalam Pembelajaran Tematik Di Sekolah Dasar," J. Pendidik. Teor. Penelitian, dan Pengemb., vol. 1, no. 5, pp. 984988, 2016.

[11] N. U. Hadi, N. Abdullah, and I. Sentosa, "An easy approach to exploratory factor analysis: Marketing perspective,” J. Educ. Soc. Res., vol. 6, no. 1, p. 215, 2016.

[12] E. Vrieling, A. Van den Beemt, and M. De Laat, "What's in a name: Dimensions of social learning in teacher groups," Teach. Teach., vol. 22, no. 3, pp. 273-292, 2016.

[13] J. W. van Hulst, "De Beginselleer van Hoogvelds Pedagogiek.--," 1962.

[14] D. Bayram-Jacobs et al., "Science teachers' pedagogical content knowledge development during enactment of socioscientific curriculum materials," J. Res. Sci. Teach., vol. 56, no. 9, pp. 1207-1233, 2019.

[15] H. J. Pentury and A. D. Anggraeni, "Enriching Teachers' Pedagogical Strategy using the Role of Global Competence Learning Model," J. Pendidik. Progresif, vol. 9, no. 1, pp. 29-39, 2019.

[16] G. Sonia, Educational research and innovation pedagogical knowledge and the changing nature of the teaching profession. OECD Publishing, 2017.

[17] B. Kartowagiran, S. Hadi, N. Wahyumiani, F. Alfarisa, and W. Pusporini, "Effectiveness of the AA ' $4 \mathrm{C}$ ' authentic assessment model: A single-case-research (SCR)," New Educ. Rev., vol. 57, no. 3, pp. 200-209, 2019.

[18] A. Wijiastuti and S. M. Budiyanto, "The Evaluation of Field Experience Program in Special Education Department: Pedagogy Competence of Master Students," in 3rd International Conference on Special Education (ICSE 2019), 2019, pp. 63-66.

[19] E. W. Prihono, J. K. Syahruzah, M. M. Magiman, and G. K. Kassymova, "Scoring Instrument Development Of Character Education Based On Local Culture For Elementary School Students," PalArch's J. Archaeol. Egypt/Egyptology, vol. 17, no. 3, pp. 275-290, 2020.

[20] M. C. Howard, "A review of exploratory factor analysis decisions and overview of current practices: What we are doing and how can we improve?," Int. J. Hum. Comput. Interact., vol. 32, no. 1, pp. 51-62, 2016.

[21] H. Retnawati, "Analisis kuantitatif instrumen penelitian," Yogyakarta Parama Publ., 2016.

[22] J. C. Watson, "Establishing evidence for internal structure using exploratory factor analysis," Meas. Eval. Couns. Dev., vol. 50, no. 4, pp. 232-238, 2017.

[23] D. L. Bandalos and S. J. Finney, "Factor analysis: Exploratory and confirmatory," in The reviewer's guide to quantitative methods in the social sciences, Routledge, 2018, pp. 98-122.

[24] R. L. Gorsuch, Factor analysis (2nd ed.). Hillsdale, NJ: Erlbaum, 1983.

[25] J. Supranto, "Analisis Multivariat Arti dan Interpretasi,” Jakarta: Rineka Cipta, 2004.

[26] F. L. Bookstein, "A method of factor analysis for shape coordinates." Wiley Online Library, 2017.

[27] H. S. Park, R. Dailey, and D. Lemus, "The use of exploratory factor analysis and principal components analysis in communication research," Hum. Commun. Res., vol. 28, no. 4, pp. 562-577, 2002.

[28] B. Kartowagiran, "Kinerja guru profesional (Guru pasca sertifikasi)," J. Cakrawala Pendidik., vol. 3, no. 3, 2011.

[29] T. Taniredja and M. Abduh, "Pedagogical, personality, social and professional competence in correlation with teachers' performance (Correlational study of junior high school teacher at SMPN 3 Purwokerto)," in The 2nd International Conference on Science, Technology, and Humanity, 2016, pp. 264-272.

[30] D. A. Kurniawan, F. Chan, P. Nugroho, R. A. Pratama, and R. Septiasari, "Identification: The effect of mathematical competence on pedagogic competency of prospective teacher," Humanit. Soc. Sci. Rev., vol. 7, no. 4, pp. 85$92,2019$. 